University of Nebraska - Lincoln

DigitalCommons@University of Nebraska - Lincoln

$12-2010$

\title{
A concise synthesis of $\boldsymbol{\beta}$-sitosterol and other phytosterols
}

Jiliang Hang

University of Nebraska-Lincoln, jhang@huskers.unl.edu

Patrick Dussault

University of Nebraska-Lincoln, pdussault1@unl.edu

Follow this and additional works at: https://digitalcommons.unl.edu/chemistrydussault

Part of the Chemistry Commons

Hang, Jiliang and Dussault, Patrick, "A concise synthesis of $\beta$-sitosterol and other phytosterols" (2010). Patrick Dussault Publications. 14.

https://digitalcommons.unl.edu/chemistrydussault/14

This Article is brought to you for free and open access by the Published Research - Department of Chemistry at DigitalCommons@University of Nebraska - Lincoln. It has been accepted for inclusion in Patrick Dussault Publications by an authorized administrator of DigitalCommons@University of Nebraska - Lincoln. 


\title{
A concise synthesis of $\beta$-sitosterol and other phytosterols
}

\author{
Jiliang Hang and Patrick Dussault \\ Department of Chemistry, University of Nebraska-Lincoln, 809 Hamilton Hall, Lincoln, NE 68588-0304 \\ Corresponding author — P. Dussault, email pdussault1@unl.edu
}

\begin{abstract}
A convenient synthesis of sidechain-modified phytosterols is achieved via a temporary masking of the stigmasterol 5,6-alkene as an epoxide. Following performance of the desired modification, the alkene is regenerated through a mild deoxygenation. The approach is applied to the syntheses of $\beta$-sitosterol and campesterol acetate, and suggests a facile route to the $(Z)$-isomers of $\Delta^{22-23}$ phytosterols.
\end{abstract}

Keywords: sitosterol, campesterol, phytosterol, synthesis, epoxide, deoxygenation

\section{Introduction}

Phytosterols and their derivatives are widely applied in the food and cosmetic industries, and have recently received a great deal of attention as nutraceutical additives [1-3]. Phytosterols have also attracted attention as inhibitors of sarcoplasmic reticulum calcium ATPase and potassium ion channels $[4,5]$. As part of a collaboration investigating the structural influences on uptake and processing of sterol esters [6], we required semipreparative amounts of $\beta$-sitosterol. However, $\beta$-sitosterol is commercially available in preparative amounts only as mixtures with other phytosterols, including stigmasterol, campesterol, and/or brassicasterol (Figure 1); reported separations are relatively laborious $[7,8]$.

Two routes have been reported for the synthesis of $\beta$-sitosterol from stigmasterol, which is available in pure form. The first, selective hydrogenation of the sidechain $\Delta^{22-23}$ alkene [9], was found to produce $\beta$-sitosterol contaminated with varying amounts of recovered stigmasterol as well as the fully saturated stigmastanol [10]. The second approach, which has been applied to the synthesis of sitosterol and related sterols (Figure 2), circumvents the need for selective hydrogenation by protecting the $\Delta^{5-6}$ alkene as a cyclopropyl carbinyl ether $[11,12]$. Following hydrogenation of the $\Delta^{22-23}$ double bond, solvolysis of the cyclopropane reintroduces both the $\mathrm{C}_{3}$ alcohol and the $\Delta^{5-6}$ alkene. Although we found the latter approach very useful as a means of obtaining very pure samples of $\beta$-sitosterol, semipreparative applications were challenging in terms of removal of sterol methyl ether byproducts.
We now report a new strategy for the synthesis of sidechain-modified phytosterols based upon protection of the $\Delta^{5-6}$ alkene as an epoxide. The approach is illustrated with syntheses of $\beta$-sitosterol and campesterol acetate.

\section{Experimental}

\subsection{General experimental procedures}

$\mathrm{AlI}_{3}$ and $\mathrm{Cu}\left(\mathrm{MnO}_{4}\right)_{2}$ were prepared by literature procedures [13, 14]. All other reagents and solvents were used as supplied commercially, except $\mathrm{CH}_{2} \mathrm{Cl}_{2}\left(\mathrm{CaH}_{2}\right)$ and THF $\left(\mathrm{Na}, \mathrm{Ph}_{2} \mathrm{CO}\right)$ which were distilled from the indicated reagent under an atmosphere of $\mathrm{N}_{2}$. Melting points are uncorrected. Unless noted, NMR spectra were acquired at $400 \mathrm{MHz}\left({ }^{1} \mathrm{H}\right)$ or $100 \mathrm{MHz}\left({ }^{13} \mathrm{C}\right)$ in $\mathrm{CDCl}_{3}$; individual peaks are reported as: multiplicity, integration, coupling constant in Hz. IR spectra were recorded as neat films on a ZnSe crystal with selected absorbances reported in $\mathrm{cm}^{-1}$. Mass spectroscopy was conducted at the Nebraska Center for Mass Spectrometry.

\subsection{Stigmasterol acetate (2)}

Stigmasterol acetate was prepared as a white solid (97\%, mp 138$140{ }^{\circ} \mathrm{C}$ ) by a variant of the procedure of Wang et al. [15]. Other physical and spectral data were identical to literature values. 


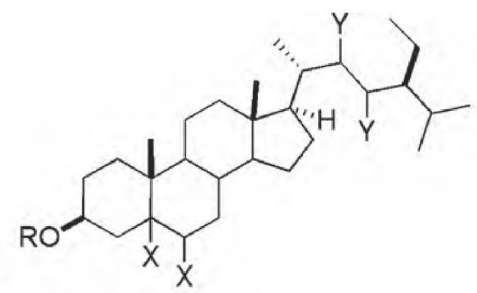

\begin{tabular}{lccc}
$\mathrm{R}$ & $\mathrm{X}$ & $\mathrm{Y}$ & \\
\hline $\mathrm{H}$ & alkene & $(E)$-alkene & Stigmasterol (1) \\
$\mathrm{Ac}$ & alkene & $(E)$-alkene & Stigmasterol acetate (2) \\
$\mathrm{H}$ & alkene & $\mathrm{H}$ & $\beta$-Sitosterol (3) \\
$\mathrm{Ac}$ & alkene & $\mathrm{H}$ & $\beta$-Sitosterol acetate (4) \\
$\mathrm{H}$ & $\mathrm{H}$ & $\mathrm{H}$ & Stigmastanol
\end{tabular}

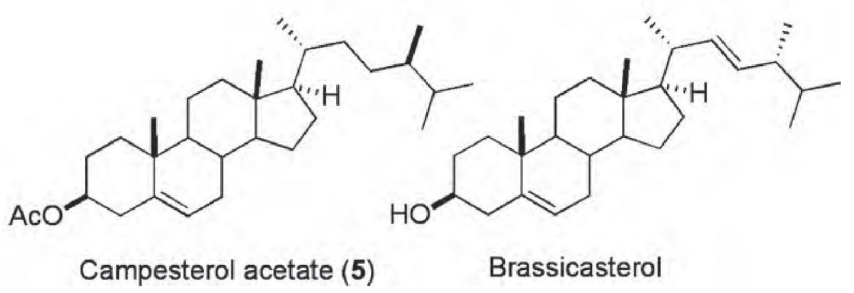

Figure 1. Structural relationship of phytosterols.

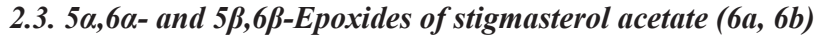

A mixture of $\mathrm{KMnO}_{4}(10 \mathrm{~g}, 60 \mathrm{mmol})$ and $\mathrm{CuSO}_{4} \cdot 5 \mathrm{H}_{2} \mathrm{O}(5.0 \mathrm{~g}, 20$ $\mathrm{mmol})$ was finely ground in a mortar and pestle [14]. Water $(0.5 \mathrm{~mL})$ was added, and the slightly wet mixture was transferred to the reaction flask. To the stirred suspension of this mixture in $25 \mathrm{~mL} \mathrm{CH}_{2} \mathrm{Cl}_{2}$ was added stigmasterol acetate $(2,2.12 \mathrm{~g}, 4.51 \mathrm{mmol})$, followed by $t$ $\mathrm{BuOH}(2.5 \mathrm{~mL})$. The reaction was heated to reflux for $1 \mathrm{~h}$ and cooled to room temperature. The reaction mixture was filtered through a silica pad, which was washed with ether. The residue obtained after concentration was recrystallized from $\mathrm{CH}_{3} \mathrm{OH}$ to give a white solid $(1.59 \mathrm{~g}, 75 \%)$ with $\mathrm{mp} 125-126^{\circ} \mathrm{C}$. NMR data indicated the product was a 1:6 mixture of the $\alpha-(\mathbf{6 a})$ and $\beta$ - $(\mathbf{6 b})$ epoxides of stigmasterol acetate [14]. Repeating this reaction with $2.23 \mathrm{~g}$ of stigmasterol acetate afforded $1.80 \mathrm{~g}(78 \%)$ of a 1:6 mixture of $\mathbf{6 a}$ and $\mathbf{6 b}$.

Approach to $5 \alpha, 6 \alpha$ - and $5 \beta, 6 \beta$-epoxides of stigmasterol acetate (6a, 6b) via peracid epoxidation: to a $0{ }^{\circ} \mathrm{C}$ solution of $2(0.308 \mathrm{~g}$, $0.66 \mathrm{mmol})$ in $\mathrm{CH}_{2} \mathrm{Cl}_{2}(20 \mathrm{~mL})$ was added mCPBA $(0.170 \mathrm{~g}, 0.76$ mmol). After $4 \mathrm{~h}$ at $0{ }^{\circ} \mathrm{C}$, the reaction was diluted with sat. aq. $\mathrm{K}_{2} \mathrm{CO}_{3}(80 \mathrm{~mL})$ and the aqueous layer was extracted with $\mathrm{CH}_{2} \mathrm{Cl}_{2}$ $(3 \times 50 \mathrm{~mL})$. The combined organic layers were dried over anhydrous $\mathrm{Na}_{2} \mathrm{SO}_{4}$ and the filtrate was concentrated in vacuo. The residue was purified by flash chromatography (hexane/EtOAc, 90:10) to afford $0.257 \mathrm{~g}(83 \%)$ of a white solid which was a 2.6:1 mixture of $\alpha-(6 \mathbf{6})$ and $\beta$-isomers $(\mathbf{6 b})$ according to ${ }^{1} \mathrm{H} \mathrm{NMR}$.

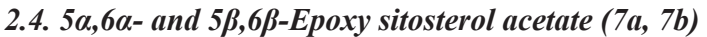

To a solution of the 1:6 mixture of $\mathbf{6 a}$ and $\mathbf{6 b}(1.35 \mathrm{~g}, 3.0 \mathrm{mmol})$ in EtOAc $(150 \mathrm{~mL})$ was added $10 \% \mathrm{Pd} / \mathrm{C}(0.32 \mathrm{~g})$, and the stirred reaction mixture was placed under an atmosphere of $\mathrm{H}_{2}$ (balloon) for 12 $\mathrm{h}$. The reaction mixture was filtered through a Celite pad, and the filtrate evaporated to furnish white solid $\left(1.28 \mathrm{~g}, 96 \%\right.$, mp $\left.113-114{ }^{\circ} \mathrm{C}\right)$ as a $1: 6$ mixture of epoxides $7 \mathbf{a}$ and $7 \mathbf{b}[8]$. Repeating this reaction on $1.76 \mathrm{~g}$ of $\mathbf{6 a} / \mathbf{6 b}$ afforded $1.75 \mathrm{~g}(99 \%)$ of a 1:6 mixture of $7 \mathbf{a}$ and $7 \mathbf{b}$.

\section{5. $\beta$-Sitosterol acetate (4)}

The 1:6 mixture of epoxides $7 \mathbf{a}$ and $7 \mathbf{b}(470 \mathrm{mg}, 1.0 \mathrm{mmol})$ was dissolved in 2:1 $\mathrm{CH}_{3} \mathrm{CN} / \mathrm{CH}_{2} \mathrm{Cl}_{2}(30 \mathrm{~mL})$. Aluminum triiodide was added (610 mg, $1.5 \mathrm{mmol}$ ) and the resulting mixture was stirred at room temperature for $10 \mathrm{~min}$. The reaction was quenched with aq. $10 \% \mathrm{Na}_{2} \mathrm{~S}_{2} \mathrm{O}_{3}$ $(100 \mathrm{~mL})$ and the resulting mixture was extracted with $\mathrm{CH}_{2} \mathrm{Cl}_{2}(3 \times$ $100 \mathrm{~mL}$ ). The combined organic layers were dried over $\mathrm{Na}_{2} \mathrm{SO}_{4}$, and the residue from the concentrated filtrate was purified by flash chromatography (hexane/EtOAc, 95:5) to give $360 \mathrm{mg}(80 \%)$ of $\mathbf{4}$ as a white solid: $\mathrm{mp} 111-112{ }^{\circ} \mathrm{C},[\alpha]_{\mathrm{D}}=-34.5\left(\mathrm{CHCl}_{3}, c=1.0\right)$. Other physical data were identical to values reported in the literature [11]. Repeating this reaction on $1.70 \mathrm{~g}$ of $7 \mathbf{a} / 7 \mathbf{b}$ afforded $1.40 \mathrm{~g}(85 \%)$ of 4 .

\section{6. $\beta$-Sitosterol (3)}

To a solution of $\beta$-sitosterol acetate $(4,240 \mathrm{mg}, 0.47 \mathrm{mmol})$ in $1: 1$ $\mathrm{CH}_{3} \mathrm{OH}: \mathrm{CH}_{2} \mathrm{Cl}_{2}(30 \mathrm{~mL})$ was added $\mathrm{K}_{2} \mathrm{CO}_{3}(140 \mathrm{mg}, 1.01 \mathrm{mmol})$. The reaction mixture was stirred at room temperature for $12 \mathrm{~h}$ and then concentrated under vacuum. The residue was extracted with $30 \mathrm{~mL} \mathrm{CH} \mathrm{Cl}_{2}$. The organic layer was washed with $30 \mathrm{~mL}$ water and dried over $\mathrm{Na}_{2} \mathrm{SO}_{4}$. The filtered organic layer was concentrated and the residue was purified through flash chromatography (hexane/EtOAc, 80:20) to give $220 \mathrm{mg}(93 \%)$ of $\beta$-sitosterol 3 as a white solid. $\mathrm{Mp} 134-135^{\circ} \mathrm{C},[\alpha]_{\mathrm{D}}=-37.0\left(\mathrm{CHCl}_{3}, c=1.0\right)$. Elemental analysis calculated for $\mathrm{C}_{29} \mathrm{H}_{50} \mathrm{O}: \mathrm{C} 83.60, \mathrm{H}$ 11.96; found: 83.99, 12.15. Other spectral properties were identical to values reported in the literature [11]. Repeating this reaction on $1.35 \mathrm{~g}$ of $\mathbf{4}$ afforded $1.20 \mathrm{~g}(98 \%)$ of beta sitosterol (3).

\section{7. (S)-2,3-Dimethylbutan-1-ol (8)}

(S)-2,3-Dimethylbutan-1-ol 8 was prepared as a colorless liquid (overall yield $60 \%,[\alpha]_{\mathrm{D}}=4.4, \mathrm{CHCl}_{3}, c=1.0$ ) by the procedure of Tietze, affording a product with spectral data identical to literature values [16].

\section{8. (S)-2-(2,3-Dimethylbutylthio)benzothiazole (9)}

To a mixture of dimethylbutanol 8 (102 mg, $1.00 \mathrm{mmol})$, 2-mercaptobenzothiazole $(183 \mathrm{mg}, 1.10 \mathrm{mmol})$ and $\mathrm{PPh}_{3}(288 \mathrm{mg}, 1.10 \mathrm{mmol})$ in freshly distilled THF (4 mL) was added diisopropyl azodicarbox-

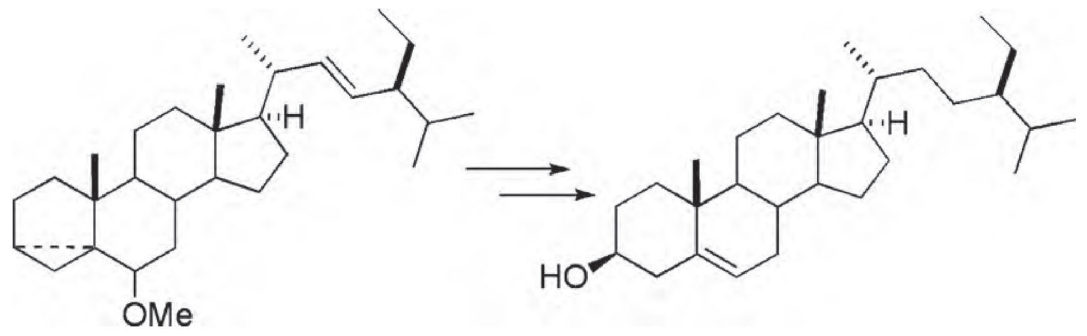

Figure 2. Selective saturation of cyclopropyl carbinyl ether. 
ylate (DIAD, $0.21 \mathrm{~mL}, 1.10 \mathrm{mmol}$ ) dropwise at $0{ }^{\circ} \mathrm{C}$ under argon. The reaction was stirred for $3 \mathrm{~h}$ at $0{ }^{\circ} \mathrm{C}$ and then quenched with water. The aqueous layer was extracted with EtOAc $(3 \times 10 \mathrm{~mL})$ and the combined organic layers were dried over anhydrous $\mathrm{Na}_{2} \mathrm{SO}_{4}$. The filtered organic layer was concentrated in vacuo and the residue purified by flash chromatography (hexane/EtOAc, 99:1) to afford thioether 9 $(228 \mathrm{mg}, 91 \%)$ as a light yellow oil. $[\alpha]_{\mathrm{D}}=42.3\left(\mathrm{CHCl}_{3}, c=1.6\right)$; IR 2957, 1455, 1426, 1057, 991, $752 \mathrm{~cm}^{-1}$; ${ }^{1} \mathrm{H}$ NMR: $\delta 7.89$ (d, $J=8.1$, $1 \mathrm{H}), 7.75(\mathrm{~d}, J=8.1,1 \mathrm{H}), 7.42(\mathrm{t}, J=7.2,1 \mathrm{H}), 7.29(\mathrm{t}, J=7.2,1 \mathrm{H})$, 3.50 (dd, $J=12.7,4.8,1 \mathrm{H}), 3.18(\mathrm{dd}, J=12.7,8.2,1 \mathrm{H}), 1.88-1.77$ $(\mathrm{m}, 2 \mathrm{H}), 1.04(\mathrm{~d}, J=6.7,3 \mathrm{H}), 0.99(\mathrm{~d}, J=6.6,3 \mathrm{H}), 0.94(\mathrm{~d}, J=6.6$, $3 \mathrm{H}) ;{ }^{13} \mathrm{C}$ NMR: $\delta 167.75,153.38,135.15,125.99,124.08,121.44$, $120.91,38.87,38.78,31.62,20.37,17.96,15.29$; HRFAB-MS $(\mathrm{m} / \mathrm{z})$ $[\mathrm{M}-\mathrm{H}]^{+}$calcd for $\left[\mathrm{C}_{13} \mathrm{H}_{18} \mathrm{NS}_{2}\right]^{+}: 252.0881$, found: 252.0875 .

\section{9. (S)-2-(2,3-Dimethylbutylsulfonyl)benzothiazole (10)}

A $0{ }^{\circ} \mathrm{C}$ solution of $9(183 \mathrm{mg}, 0.73 \mathrm{mmol})$ in EtOH $(10 \mathrm{~mL})$ was oxidized with ammonium heptamolybdate tetrahydrate $(1.8 \mathrm{~g}, 1.46$ $\mathrm{mmol})$ and $30 \% \mathrm{H}_{2} \mathrm{O}_{2}(2.5 \mathrm{~mL}, 21.9 \mathrm{mmol})$ for $2 \mathrm{~h}$. The mixture was extracted with EtOAc $(3 \times 10 \mathrm{~mL})$ and the combined organic extracts were washed with brine $(3 \times 10 \mathrm{~mL})$. The dried organic layers were filtered and the residue obtained upon concentration was purified by flash chromatography (hexane/EtOAc, 90:10) to afford sulfone $\mathbf{1 0}$ $(177 \mathrm{mg}, 86 \%)$ as a pale yellow oil. $[\alpha]_{\mathrm{D}}=15.5\left(\mathrm{CHCl}_{3}, c=3.4\right)$; IR 2961, 1470, 1324, 1140, 1085, $758 \mathrm{~cm}^{-1}$; ${ }^{1} \mathrm{H}$ NMR: $\delta 8.23$ (d, $J=$ $7.9,1 \mathrm{H}), 8.03(\mathrm{~d}, J=7.9,1 \mathrm{H}), 7.68-7.59(\mathrm{~m}, 2 \mathrm{H}), 3.59$ (dd, $J=14.4$, $3.5,1 \mathrm{H}), 3.31(\mathrm{dd}, J=14.1,8.9,1 \mathrm{H}), 2.29-2.19(\mathrm{~m}, 1 \mathrm{H}), 1.82-1.73$ $(\mathrm{m}, 1 \mathrm{H}), 1.10(\mathrm{~d}, J=6.9,3 \mathrm{H}), 0.89(\mathrm{~d}, J=6.8,3 \mathrm{H}), 0.85(\mathrm{~d}, J=6.9$, $3 \mathrm{H}) ;{ }^{13} \mathrm{C}$ NMR: $\delta 166.66,152.70,136.74,128.00,127.67,125.43$, 122.38, 58.83, 38.68, 32.47, 19.23, 17.89, 15.93; HRFAB-MS $(\mathrm{m} / \mathrm{z})$ $[\mathrm{M}-\mathrm{H}]^{+}$calcd for $\left[\mathrm{C}_{13} \mathrm{H}_{18} \mathrm{NO}_{2} \mathrm{~S}_{2}\right]^{+}: 284.0779$, found: 284.0778 .

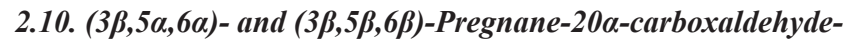 5,6-epoxy-3-yl acetate (11a, 11b)}

A $-78{ }^{\circ} \mathrm{C}$ solution of $\mathbf{6 a}, \mathbf{6 b}(\sim 1: 6$ mixture, $100 \mathrm{mg}, 0.21 \mathrm{mmol})$ in $10 \mathrm{~mL}$ of $50 / 50 \mathrm{CH}_{2} \mathrm{Cl}_{2} / \mathrm{MeOH}$ was treated with a gaseous stream of ozone $\left(2 \% \mathrm{O}_{3} / \mathrm{O}_{2}\right)$ for $5 \mathrm{~min}$. The solution was purged with pure oxygen and then solvent was removed under vacuum. The residue was redissolved in $10 \mathrm{~mL}$ of $10 / 90 \mathrm{H}_{2} \mathrm{O} / \mathrm{AcOH}$ and treated with zinc powder $(55 \mathrm{mg}, 0.84 \mathrm{mmol})$. The reaction mixture was stirred for $2 \mathrm{~h}$ at room temperature and then extracted with $50 \mathrm{~mL} \mathrm{CH}_{2} \mathrm{Cl}_{2}$. The organic layer was washed with water $(3 \times 25 \mathrm{~mL})$, then dried over anhydrous $\mathrm{Na}_{2} \mathrm{SO}_{4}$. The filtered organic layer was concentrated and the residue purified by flash chromatography (hexane/EtOAc, 90:10) to afford a 1:6 mixture of epoxides 11a and 11b as a white solid (81 mg, 99\%), mp 87-8 ${ }^{\circ} \mathrm{C}$. IR: 2950, 1727, 1367, 1262, 1238, 1042, $783 \mathrm{~cm}^{-1}$; ${ }^{1} \mathrm{H}$ NMR: $\delta 9.57(\mathrm{~d}, J=3.3,0.76 \mathrm{H}, \beta), 9.55(\mathrm{~d}, J=3.3$, $0.16 \mathrm{H}, \alpha), 4.99-4.91(\mathrm{~m}, 0.14 \mathrm{H}, \alpha), 4.81-4.73(\mathrm{~m}, 0.87 \mathrm{H}, \beta), 3.09$ (d, $J=2.2,0.88 \mathrm{H}, \beta), 2.90(\mathrm{~d}, J=4.2,0.13 \mathrm{H}, \alpha), 2.38-2.31(\mathrm{~m}, 1 \mathrm{H})$, $2.13-1.82(\mathrm{~m}, 9 \mathrm{H}), 1.54-0.89(\mathrm{~m}, 20 \mathrm{H}), 0.7(\mathrm{~s}, 3 \mathrm{H}) ;{ }^{13} \mathrm{C} \mathrm{NMR}: \delta$ $204.95,170.52,71.25,63.41,62.48,55.39,51.05,50.93,49.42$, 42.89, 39.43, 37.95, 36.67, 35.06, 32.41, 29.74, 27.17, 26.97, 24.54, 21.84, 21.30, 17.03, 13.40, 12.11; HRFAB-MS $(\mathrm{m} / \mathrm{z})[\mathrm{M}-\mathrm{Li}]^{+}$calcd for $\left[\mathrm{C}_{24} \mathrm{H}_{36} \mathrm{LiO}_{4}\right]^{+}:$395.2774, found: 395.2778 .

\subsection{1. $(3 \beta, 5 \alpha, 6 \alpha, 22 Z)$ - and $(3 \beta, 5 \beta, 6 \beta, 22 Z)$-Ergost-5,6-epoxy-22-en- 3-yl acetate $(12 a, 12 b)$}

To a $78^{\circ} \mathrm{C}$ solution of sulfone $\mathbf{1 0}(62 \mathrm{mg}, 0.22 \mathrm{mmol})$ in THF $(5 \mathrm{~mL})$ was dropwise added LiHMDS $(0.22 \mathrm{~mL}$, nominally $1 \mathrm{M}$ in THF, $0.22 \mathrm{mmol})$. The reaction was stirred for $1 \mathrm{~h}$, whereupon the mixture of aldehydes 11a and 11b $(\sim 1: 6,85 \mathrm{mg}, 0.22 \mathrm{mmol})$ was added in 5 $\mathrm{mL}$ of THF. Stirring was continued for $1 \mathrm{~h}$, and reaction was gradually warmed to room temperature. The reaction was quenched by 15 $\mathrm{mL}$ water and extracted with EtOAc $(3 \times 10 \mathrm{~mL})$. The combined organic layers were dried over anhydrous $\mathrm{Na}_{2} \mathrm{SO}_{4}$ and filtered. The residue obtained upon concentration was purified by flash chromatography (hexane/EtOAc, 95:5) to afford a 1:16 mixture of epoxides 12a and $\mathbf{1 2 b}$ as a white solid (90 mg, $90 \%$ ), mp $145-147^{\circ} \mathrm{C}$. IR: 2950 , 2867, 1743, 1368, 1037, $764 \mathrm{~cm}^{-1}$; ${ }^{1} \mathrm{H}$ NMR: $\delta 5.02(\mathrm{dd}, J=10.9$, $9.9,2 \mathrm{H}), 4.83-4.73(\mathrm{~m}, 1 \mathrm{H}), 3.09$ (d, $J=2.0,0.95 \mathrm{H}, \beta), 2.91$ (d, $J$ $=4.4,0.06, \alpha), 2.43-2.33(\mathrm{~m}, 1 \mathrm{H}), 2.21-1.80(\mathrm{~m}, 9 \mathrm{H}), 1.68-0.83$ $(\mathrm{m}, 31 \mathrm{H}), 0.69(\mathrm{~s}, 3 \mathrm{H}) ;{ }^{13} \mathrm{C}$ NMR: $\delta 170.56,135.13,131.22,71.34$, 63.58, 62.52, 56.27, 56.02, 51.02, 42.18, 39.72, 38.32, 38.01, 36.68, $35.04,34.48,33.35,32.43,29.74,28.32,27.20,24.15,21.92,21.34$, 20.55, 20.36, 19.94, 18.63, 17.06, 12.06; HRFAB-MS $(\mathrm{m} / \mathrm{z})[\mathrm{M}-\mathrm{H}]^{+}$ calcd for $\left[\mathrm{C}_{30} \mathrm{H}_{49} \mathrm{O}_{3}\right]^{+}: 457.3682$, found: 457.3668 .

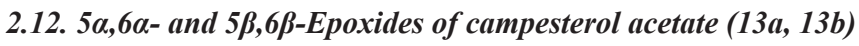

The mixture of epoxides 12a and 12b (30 mg, $0.065 \mathrm{mmol}$ ) was dissolved in $5 \mathrm{~mL}$ EtOAc. $10 \% \mathrm{Pd} / \mathrm{C}(7 \mathrm{mg})$ was added, and the reaction mixture was stirred at room temperature under an atmosphere of $\mathrm{H}_{2}$ (balloon) for $12 \mathrm{~h}$. The reaction mixture was filtered through a Celite pad, and the filtrate evaporated to a white solid $(28 \mathrm{mg}, 94 \%$, mp $110-111^{\circ} \mathrm{C}$ ) as $1: 9$ mixture of epoxides 13a and 13b. IR: 2953, 2867, 1729, 1367, 1263, 1043, $784 \mathrm{~cm}^{-1}$; ${ }^{1} \mathrm{H}$ NMR: $\delta$ 5.01-4.93 $(\mathrm{m}, 0.15 \mathrm{H}, \alpha), 4.83-4.73(\mathrm{~m}, 0.96 \mathrm{H}, \beta), 3.09(\mathrm{~d}, J=2.1,0.9 \mathrm{H}, \beta)$, $2.90(\mathrm{~d}, J=4.4,0.1 \mathrm{H}, \alpha), 2.12-1.8(\mathrm{~m}, 8 \mathrm{H}), 1.58-0.77(\mathrm{~m}, 37 \mathrm{H})$, $0.65(\mathrm{~s}, 3 \mathrm{H}) ;{ }^{13} \mathrm{C}$ NMR: $\delta 170.54,71.34,63.58,62.51,56.19,56.14$, 50.97, 42.28, 39.78, 38.81, 38.01, 36.66, 35.82, 35.03, 33.65, 32.47, $32.41,30.26,29.73,28.14,27.21,24.18,21.92,21.31,20.19,18.66$, 18.24, 17.03, 15.37, 11.76; HRFAB-MS $(\mathrm{m} / \mathrm{z})[\mathrm{M}-\mathrm{H}]^{+}$calcd for $\left[\mathrm{C}_{30} \mathrm{H}_{51} \mathrm{O}_{3}\right]^{+}:$459.3838, found: 459.3820 .

\subsection{Campesterol acetate (5)}

The mixture of epoxides 13a and 13b $(28 \mathrm{mg}, 0.061 \mathrm{mmol})$ was dissolved in 2:1 $\mathrm{CH}_{3} \mathrm{CN} / \mathrm{CH}_{2} \mathrm{Cl}_{2}(3 \mathrm{~mL})$. Aluminum triiodide $(37 \mathrm{mg}$, $0.091 \mathrm{mmol}$ ) was added and the resulting mixture was stirred at room temperature for $40 \mathrm{~min}$. The reaction was quenched with aq. $10 \% \mathrm{Na}_{2} \mathrm{~S}_{2} \mathrm{O}_{3}(10 \mathrm{~mL})$ and the resulting mixture was extracted with $\mathrm{CH}_{2} \mathrm{Cl}_{2}(3 \times 10 \mathrm{~mL})$. The combined organic layers were dried over anhydrous $\mathrm{Na}_{2} \mathrm{SO}_{4}$, and the residue from the concentrated filtrate was purified by flash chromatography (hexane/EtOAc, 95:5) to give 24 mg (91\%) campesterol acetate (5) as a white solid. Mp $130-131{ }^{\circ} \mathrm{C}$, $[\alpha]_{\mathrm{D}}=-32\left(\mathrm{CHCl}_{3}, c=0.7\right)$; IR 2954, 1730, 1367, 1247, 1037, 735 $\mathrm{cm}^{-1}$; ${ }^{1} \mathrm{H}$ NMR: $\delta 5.39(\mathrm{~d}, J=4.8,1 \mathrm{H}), 4.66-4.58(\mathrm{~m}, 1 \mathrm{H}), 2.33(\mathrm{~d}, J$ $=7.9,2 \mathrm{H}), 2.05(\mathrm{~s}, 3 \mathrm{H}), 1.90-1.84(\mathrm{~m}, 2 \mathrm{H}), 1.59-0.78(\mathrm{~m}, 38 \mathrm{H}), 0.68$ (s, 3H); ${ }^{13} \mathrm{C}$ NMR: $\delta 170.56,139.66,122.66,73.99,56.69,56.08$, 50.02, 42.31, 39.73, 38.84, 38.12, 36.99, 36.59, 35.90, 33.70, 32.43, $31.90,31.86,30.27,28.24,27.78,24.29,21.46,21.03,20.22,19.32$, $18.70,18.26,15.38,11.87$; HRFAB-MS $(\mathrm{m} / \mathrm{z})[\mathrm{M}-\mathrm{Na}]^{+}$calcd for $\left[\mathrm{C}_{30} \mathrm{H}_{50} \mathrm{O}_{2} \mathrm{Na}\right]^{+}:$465.3709, found: 465.3703 . Elemental analysis calculated for $\mathrm{C}_{30} \mathrm{H}_{50} \mathrm{O}_{2}: \mathrm{C} 81.20, \mathrm{H} 11.38$; found: 81.39, 11.39. The ${ }^{1} \mathrm{H}$ NMR data matched that of a literature report [17].

\section{Results and discussion}

Our synthesis of $\beta$-sitosterol (3) is illustrated in Scheme 1. Selective epoxidation of the $\Delta^{5-6}$ alkene of stigmasterol acetate (2) with copper permanangate formed a $6: 1$ mixture of the $5 \beta, 6 \beta$ - and $5 \alpha, 6 \alpha-$ epoxides $\mathbf{6 b}$ and $\mathbf{6 a}[14,18]$. Hydrogenation over $\mathrm{Pd} / \mathrm{C}$ cleanly furnished a 1:6 mixture of sitosterol epoxides $\mathbf{7 a}$ and $\mathbf{7 b}$. Deoxygen- 


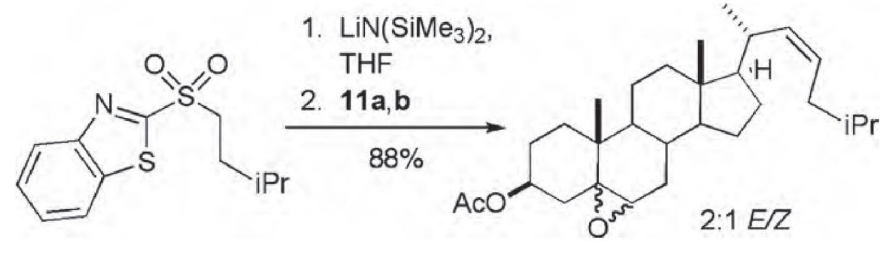

Figure 3. Generality of $Z$-selective olefination.
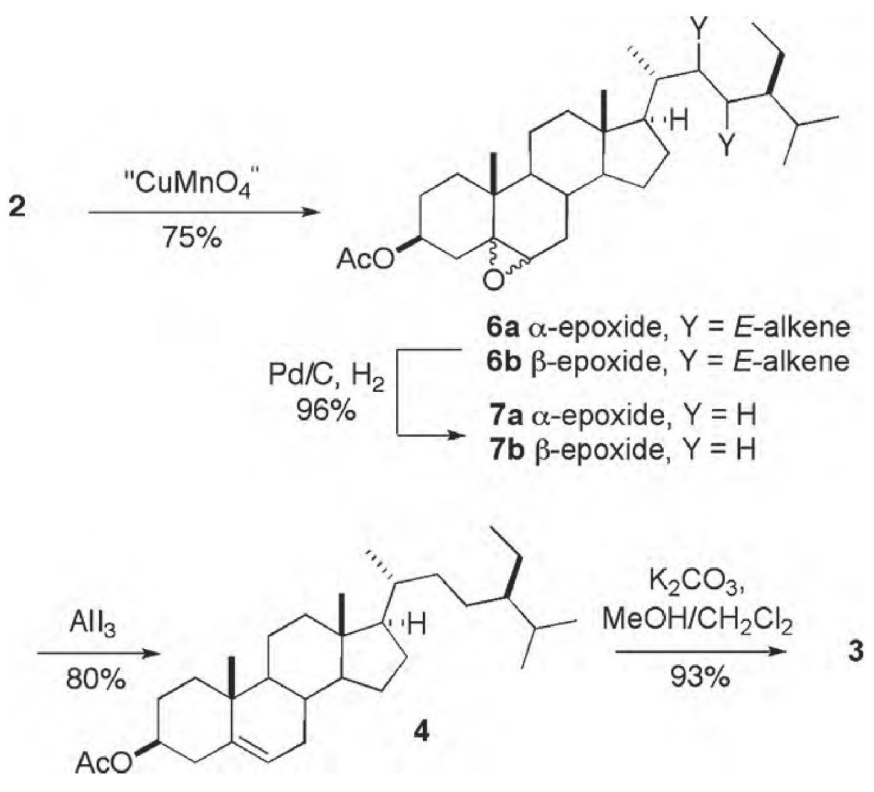

Scheme 1. Synthesis of sitosterol.

ation of the saturated epoxides with $\mathrm{AlI}_{3}$ [13] proceeded rapidly to furnish a good yield of $\beta$-sitosteryl acetate 4 . Saponification afforded pure $\beta$-sitosterol $(3)$, with $\mathrm{mp} 134-135^{\circ} \mathrm{C}$ and $[\alpha]_{\mathrm{D}}=-37.0[8,19]$.

Epoxidation with the commercially available peracid mCPBA also gave good selectivity for the $\Delta^{5-6}$ alkene, but now produced a 2.6:1 mixture of stigmasterol oxides favoring the $\alpha$-isomer (6a). Hydrogenation proceeded uneventfully to furnish the corresponding mixture of sitosterol oxides $\mathbf{7 a}$ and $\mathbf{7 b}$. However, attempted deoxygenation under the same conditions as employed earlier $\left(\mathrm{AlI}_{3}, 10\right.$ min, $\mathrm{CH}_{3} \mathrm{CN} / \mathrm{CH}_{2} \mathrm{Cl}_{2}$ ) now furnished only $33 \%$ of $\beta$-sitosterol acetate (4), accompanied by a significant amount (estimated $>60 \%$ by mass) of a more polar product which yellowed immediately upon exposure to room light. The formation of the byproduct could be avoided almost completely by allowing the deoxygenation to proceed for $40 \mathrm{~min}$. Alternatively, the byproduct could be converted to 4 by treatment with additional $\mathrm{AlI}_{3}$. The results suggest that the deoxygenation of the $\alpha$ - and $\beta$-epoxides proceeds at very different rates, with the $5 \alpha, 6 \alpha$ diastereomer (6a) reacting via the intermediacy of a semistable iodohydrin.

As illustrated in Scheme 2, our strategy also provides a facile means of preparing other sidechain-modified phytosterols. For example, ozonolysis of the mixture of $\mathbf{6 a / 6 b}$ furnished an approximately 1:6 mixture of aldehydes 11a and 11b. Julia-Kocienski olefination, using an enantiomerically pure sulfone (10) derived from $(S)$-2,3dimethylbutanol (8) [16] furnished exclusively alkene 12 [20], corresponding to the monoepoxide of the $Z$-isomer of crinosterol [21]. Hydrogenation, followed by deoxygenation of the epoxide as before, furnished campesterol acetate (5).
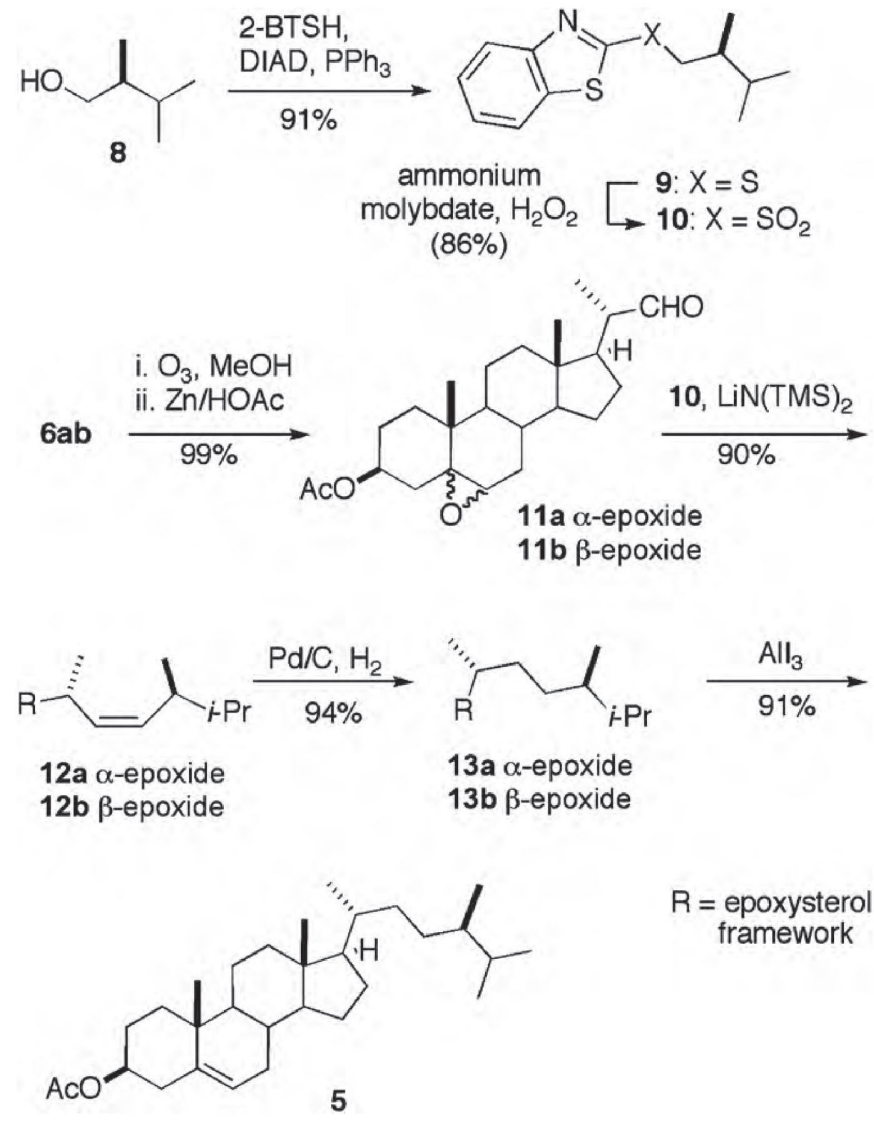

$R=$ epoxysterol
framework

Scheme 2. Synthesis of campesterol acetate.

The selective formation of $Z$-alkenes is unusual in Julia couplings [22] and we investigated the olefination of 11a and 11b with a known sulfone derived from isobutyl alcohol (Figure 3) [23]. This reaction also selectively furnished the $Z$-alkene; the lower selectivity $(2: 1)$ compared with that observed for the synthesis of 12a and 12b may reflect the reduced degree of steric encumbrance in this model system. The ability to readily prepare $Z$-isomers of phytosterols opens the door to a number of steroid analogs not available from synthetic routes based upon Claisen rearrangements of $\mathrm{C}_{22}$ allylic alcohols [12].

\section{Conclusions}

The formation of $\beta$-sitosterol has been achieved in $52 \%$ overall yield from commercially available stigmasterol using relatively simple chemistry and via easily purified intermediates. The core strategy, protection of the $\Delta^{5-6}$ alkene as an epoxide, holds potential for the synthesis of other phytosterols as well as unnatural analogs.

Acknowledgments - We thank Professor Tim Carr (University of Nebraska-Lincoln, Department of Nutrition and Health Sciences) for useful discussions. This research was supported by a USDANRI competitive grant (2007-35200-18298). Portions of this work were conducted in facilities remodeled with support from NIH (RR016544-01). NMR spectra were acquired, in part, on spectrometers purchased with NSF support (MRI 0079750, CHE 0091975). 


\section{References}

[1] M.H. Moghadasian, Pharmacolgical properties of plant sterols: in vivo and in vitro observations. Life Sci, 67 (2000), pp. 605-615.

[2] V. Piironen, D.G. Lindsay, T.A. Miettinen, J. Toivo and A.M. Lampi, Plant sterols: biosynthesis, biological function and their importance to human nutrition. J Sci Food Agric, 80 (2000), pp. 939-966.

[3] W.H. Ling and P.J.H. Jone, Dietary phytosterols: a review of metabolism, benefits and side effects. Life Sci, 57 (1995), pp. 195-206.

[4] L. Bao, Y. Li, S.X. Deng, D. Landry and I. Tabas, Sitosterol-containing lipoproteins trigger free sterol-induced caspase-independent death in ACAT-competent macrophages. J Biol Chem, 281 (2006), pp. 33635-33649.

[5] W. Promprom, P. Kupittayanant, K. Indrapichate, S. Wray and S. Kupittayanant, The effects of pomegranate seed extract and $\beta$-sitosterol on rat uterine contractions. Reprod Sci, 17 (2010), pp. 288-296.

[6] A.W. Brown, J. Hang, P.H. Dussault and T. Carr, Plant sterol and stanol substrate specificity of pancreatic cholesterol ester lipase, . J Nutr Biochem, (2009), online July 16, 2009; H.E. Rasmussen, D.M. Guderian, C.A. Wray, P.H. Dussault, V.L. Schlegel and T. Carr, Reduction in cholesterol absorption is enhanced by stearate-enriched plant sterol esters in hamsters. J Nutr, 136 (2006), pp. 2722-2727.

[7] R.T. Holman, W.O. Lundberg and T. Malkin, Progress in the Chemistry of Fats and Other Lipids, vol. 1 Pergamon Press, London (1952) Chapter 2 .

[8] X. Zhang, P. Geoffroy, M. Miesch, D. Julien-David, F. Raul and D. Aoudǐe-Werner, et al. Gram-scale chromatographic purification of $\beta$-sitosterol: synthesis and characterization of $\beta$-sitosterol oxides. Steroids, 70 (2005), pp. 886-895.

[9] H.W. Kircher and F.U. Rosenstein, Purification of sitosterol. Lipids, 8 (1973), pp. 97-100.

[10] For an overview of stigmasterol hydrogenation, see: P. Geoffroy, D. Julien-David, E. Marchioni, F. Raul, D. Aoudǐe-Werner and M. Miesch, Synthesis of highly pure oxyphytosterols and (oxy)phytosterol esters: Part I. Regioselective hydrogenation of stigmasterol: an easy access to oxyphytosterols, Steroids, 73 (2008), pp. 702-707.

[11] J.A. Steele and E. Mosettig, The Solvolysis of Stigmasteryl tosylate. J Org Chem, 28 (1963), pp. 571-572.; F.O. McCarthy, J. Chopra, A. Ford, S.A. Hogan, J.P. Kerry, N.M. O'Brien, E. Ryan and A.R. Maquire, Synthesis, isolation and characterization of $\beta$-sitosterol and $\beta$-sitosterol oxide derivatives. Org Biomol Chem, 3 (2005), pp. 3059-3065.
[12] V.A. Khripach, V.N. Zhabinskii, O.V. Konstantinova, N.B. Khripach, A.V. Antonchick, A.P. Antonchick and B. Schneider, Preparation of (25R)- and (25S)-26-functionalized steroids as tools for biosynthetic studies of cholic acids, . Steroids, 70 (2005), pp. 551-562 For an application to sidechain-modified steroids, see:.

[13] P. Sarmah and N.C. Barua, Aluminum triiodide: a convenient reagent for deoxygenation of oxiranes. Tetrahedron Lett, 29 (1988), pp. $5815-5816$.

[14] M.S. Syamala, J.J. Das, S. Baskaran and S. Chandrasekaran, A novel and highly $\beta$-selective epoxidation of $\Delta^{5}$-unsaturated steroids with permanganate ion. J Org Chem, 57 (1992), pp. 1928-1930; Y. Baqi, S. Giroux and E.J. Corey, A study of the epoxidation of cycloolefins by the $t$ BuOH copper-permanganate system. Org Lett, 11 (2009), pp. 959-961.

[15] S.M. Wang, Y.B. Zhang, H.M. Liu, G.B. Yu and K.R. Wang, Mild and selective deprotection method of acetylated steroids and diterpenes by dibutyltin oxide. Steroids, 72 (2007), pp. 26-30.

[16] L.F. Tietze, C. Raith, C.C. Brazel, S. Hoelsken and J. Magull, Enantioselective synthesis of 2-substituted alcohols using (+)-(1S,2S)-pseudoephedrine as chiral auxiliary. Synthesis, (2008), pp. 229-236.

[17] T. Akihisa, N. Tanaka, T. Yokota, N. Tanno and T. Tamura, $5 \alpha$-Cholest-

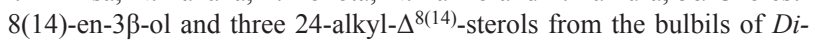
oscorea batatas. Phytochemistry, 30 (1991), pp. 2369-2372.

[18] Attempts to perform the $\mathrm{Cu}\left(\mathrm{MnO}_{4}\right)_{2}$ oxidation on unprotected stigmasterol resulted in formation of numerous byproducts.

[19] V.A. Khripach, V.N. Zhabinskii, O.V. Konstantinova, N.B. Khripach, A.P.

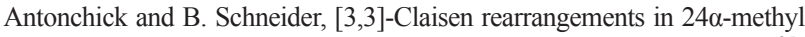
steroid synthesis: application to campesterol, crinosterol, and $\Delta^{25}$. crinosterol side chain construction. Steroids, 67 (2002), pp. 597-603.

[20] Assigned from the $10.6 \mathrm{~Hz}$ coupling constant for $\mathrm{H}_{22}-\mathrm{H}_{23}$.

[21] K. Murakami, B. Watanabe, R. Nishida, N. Mori and Y. Kuwahara, Identification of crinosterol from astigamatid mites, . Insect Biochem Mol Biol, 37 (2007), pp. 506-511 See, for example:.

[22] P.R. Blakemore, The modified Julia olefination: alkene synthesis via the condensation of metallated heteroarylalkylsulfones with carbonyl compounds. Perkins, 1 (2002), pp. 2563-2585.

[23] V. Sutoris, P. Foltinova and A. Gaplovsky, Benzothiazole compounds. XVII. 2-Alkyl- and 2-aralkylsulfonylbenzothiazoles and their antimicrobial activity. Chem Zvesti, 34 (1980), pp. 404-412; B. Bourdon, M. Corbet, P. Fontaine, P.G. Goekjian and D. Gueyrard, Synthesis of enol ethers from lactones using modified Julia olefination reagents: application to the preparation of tri- and tetrasubstituted exoglycals. Tetrahedron Lett, 49 (2008), pp. 747-749. 


\title{
Supplementary Data:
}

\section{A concise synthesis of $\beta$-sitosterol and other phytosterols}

\author{
Jiliang Hang and Patrick Dussault*
}

Department of Chemistry, University of Nebraska-Lincoln, Lincoln, NE 68588-0304

pdussault1@unl.edu

Table of Contents:

$\begin{array}{lr}\mathbf{6 a b}\left({ }^{1} \mathrm{H}\right) & 2 \\ \mathbf{6 a b}\left({ }^{13} \mathrm{C}\right) & 2 \\ \mathbf{7 a b}\left({ }^{1} \mathrm{H}\right) & 3 \\ \mathbf{7 a b}\left({ }^{13} \mathrm{C}\right) & 3 \\ \mathbf{4}\left({ }^{1} \mathrm{H}\right) & 4 \\ \mathbf{4}\left({ }^{13} \mathrm{C}\right) & 4 \\ \mathbf{3}\left({ }^{1} \mathrm{H}\right) & 5 \\ \mathbf{3}\left({ }^{13} \mathrm{C}\right) & 5 \\ \mathbf{9}\left({ }^{1} \mathrm{H}\right) & 6 \\ \mathbf{9}\left({ }^{13} \mathrm{C}\right) & 6 \\ \mathbf{1 0}\left({ }^{1} \mathrm{H}\right) & 7 \\ \mathbf{1 0}\left({ }^{13} \mathrm{C}\right) & 7 \\ \mathbf{1 1 a b}\left({ }^{1} \mathrm{H}\right) & 8 \\ \mathbf{1 1 a b}\left({ }^{13} \mathrm{C}\right) & 8 \\ \mathbf{1 2 a b}\left({ }^{1} \mathrm{H}\right) & 9 \\ \mathbf{1 2 a b}\left({ }^{13} \mathrm{C}\right) & 9 \\ \mathbf{1 3 a b}\left({ }^{1} \mathrm{H}\right) & 10 \\ \mathbf{1 3 a b}\left({ }^{13} \mathrm{C}\right) & 10 \\ \mathbf{1 4}\left({ }^{1} \mathrm{H}\right) & 11 \\ \mathbf{1 4}\left({ }^{13} \mathrm{C}\right) & 11\end{array}$



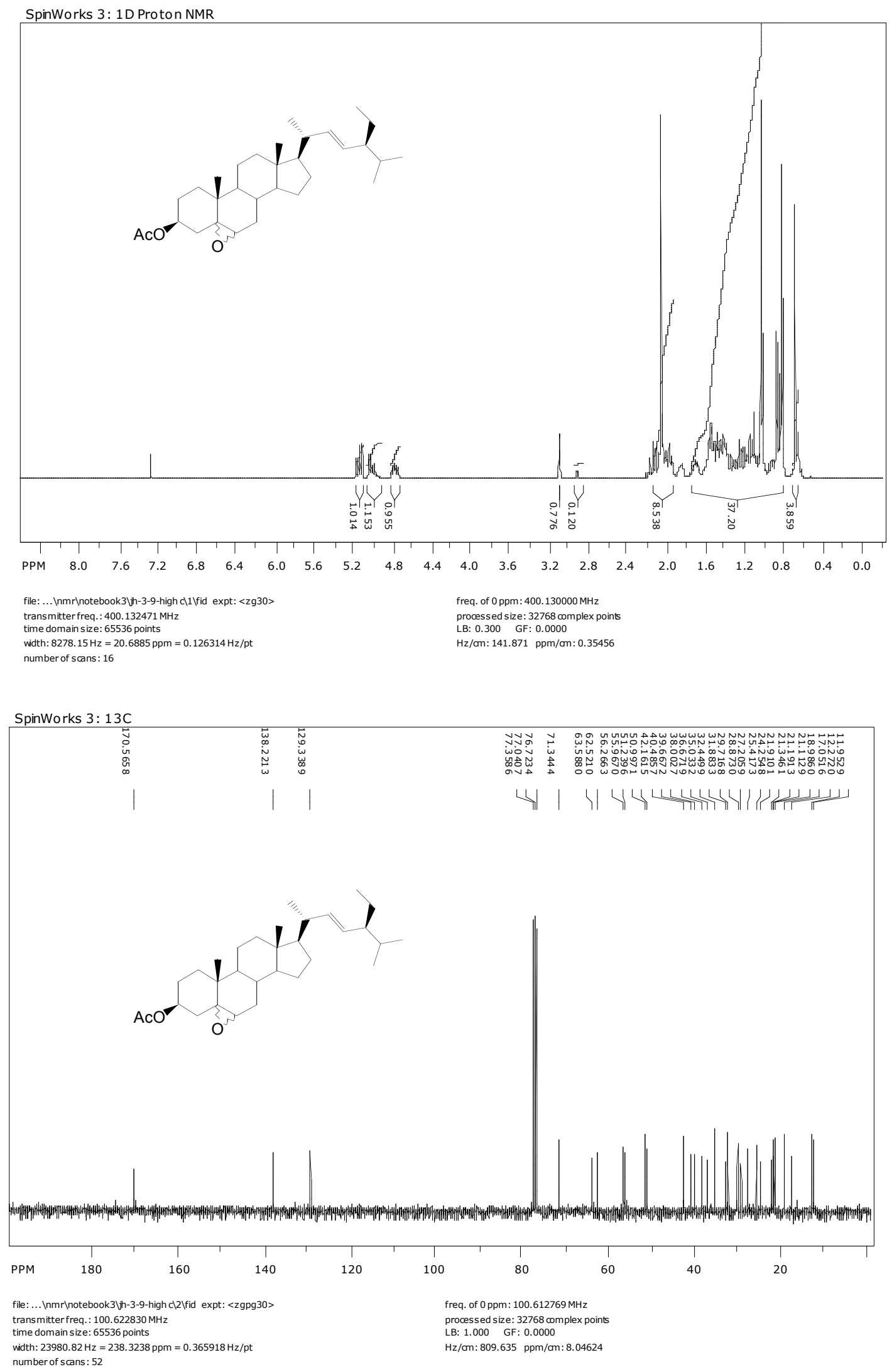

\section{${ }^{1} \mathrm{H}$ and ${ }^{13} \mathrm{C}$ of $6 \mathrm{ab}$}



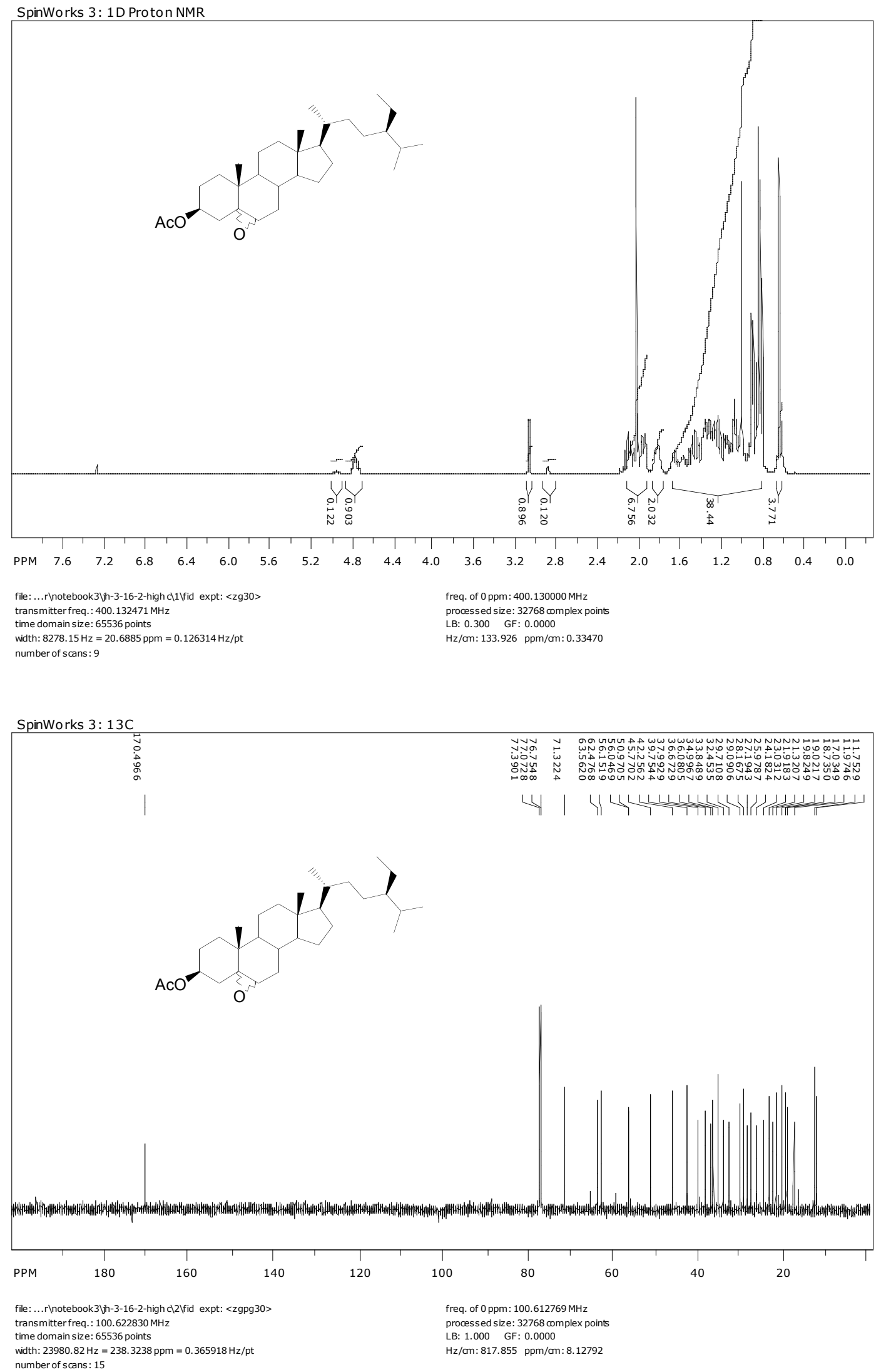

\section{${ }^{1} \mathrm{H}$ and ${ }^{13} \mathrm{C}$ of $7 \mathrm{ab}$}



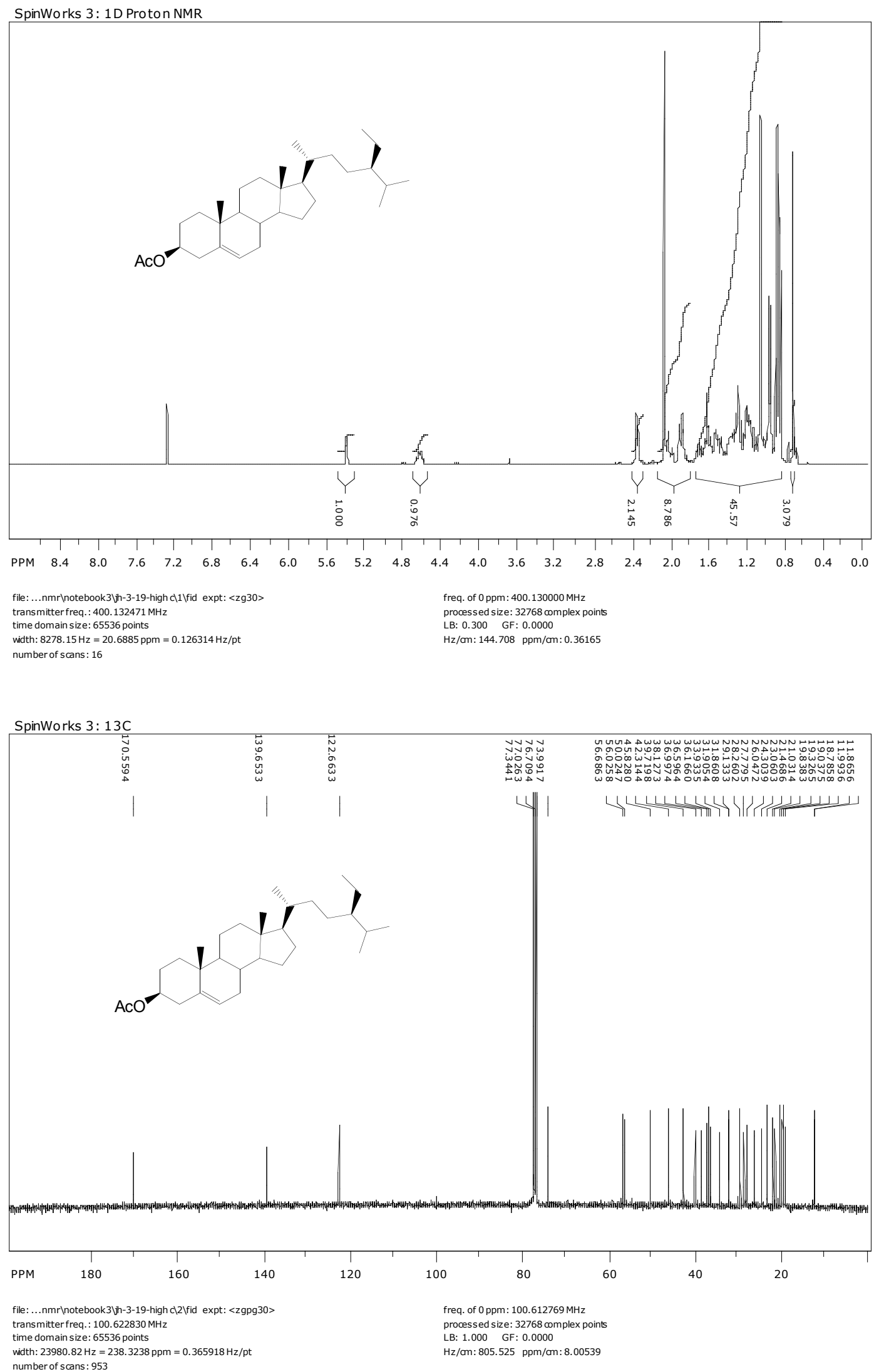

\section{${ }^{1} \mathrm{H}$ and ${ }^{13} \mathrm{C}$ of beta-sitosterol acetate (4)}



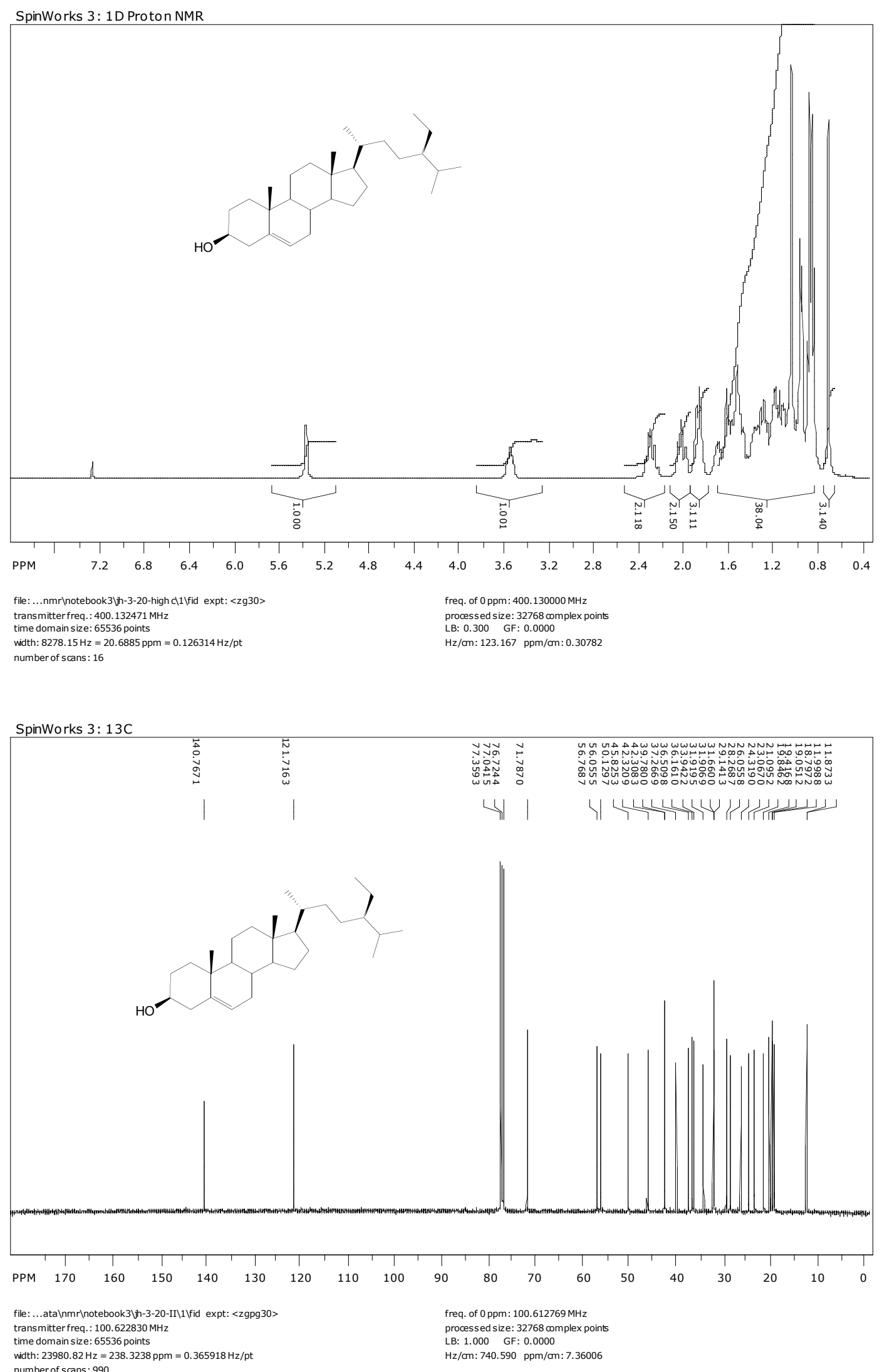

${ }^{1} \mathrm{H}$ and ${ }^{13} \mathrm{C}$ of beta-sitosterol (3) 

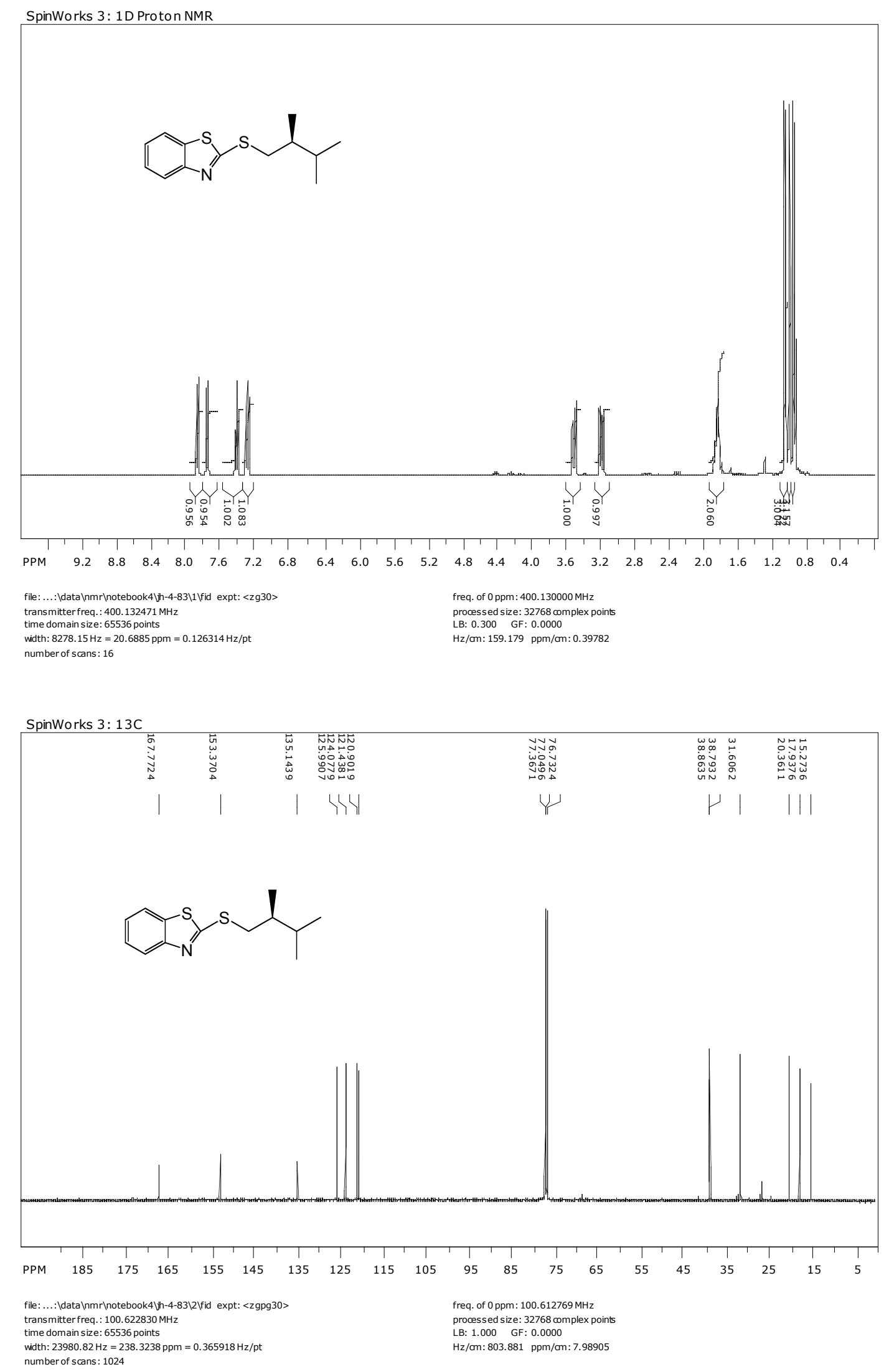

${ }^{1} \mathrm{H}$ and ${ }^{13} \mathrm{C}$ of 9 

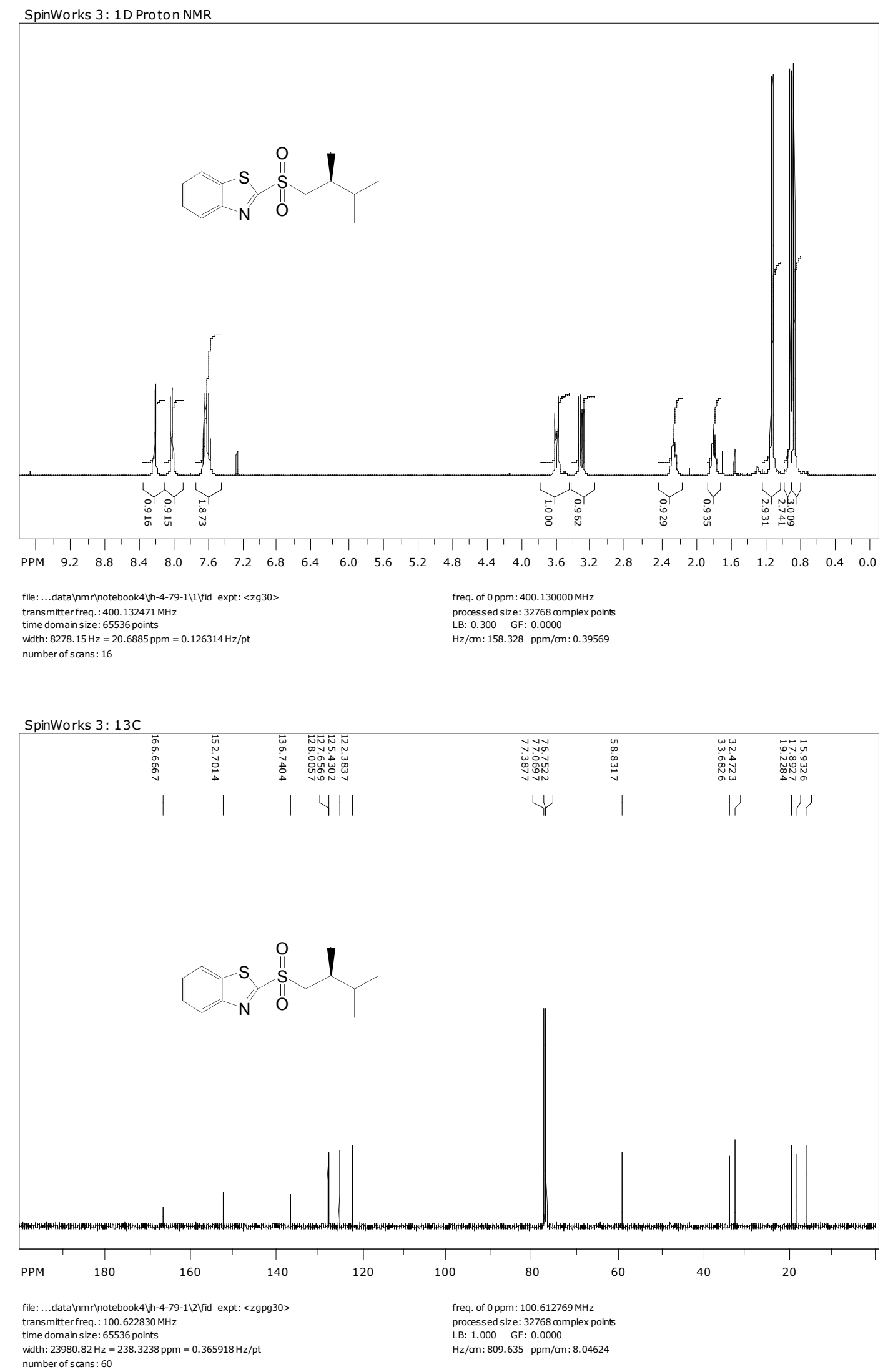

${ }^{1} \mathrm{H}$ and ${ }^{13} \mathrm{C}$ of 10 

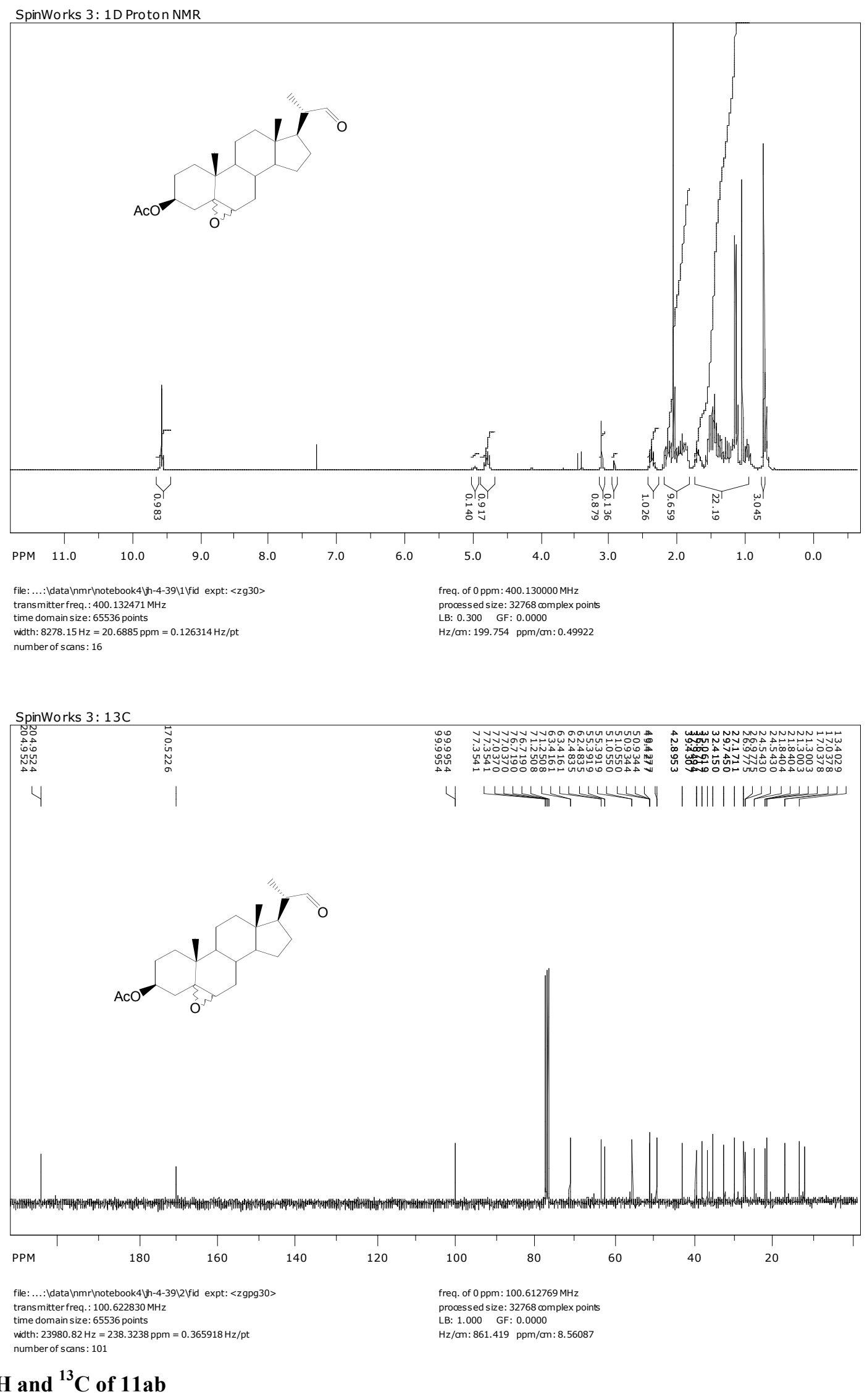

Hang and Dussault, "A concise synthesis of $\beta$-sitosterol... 

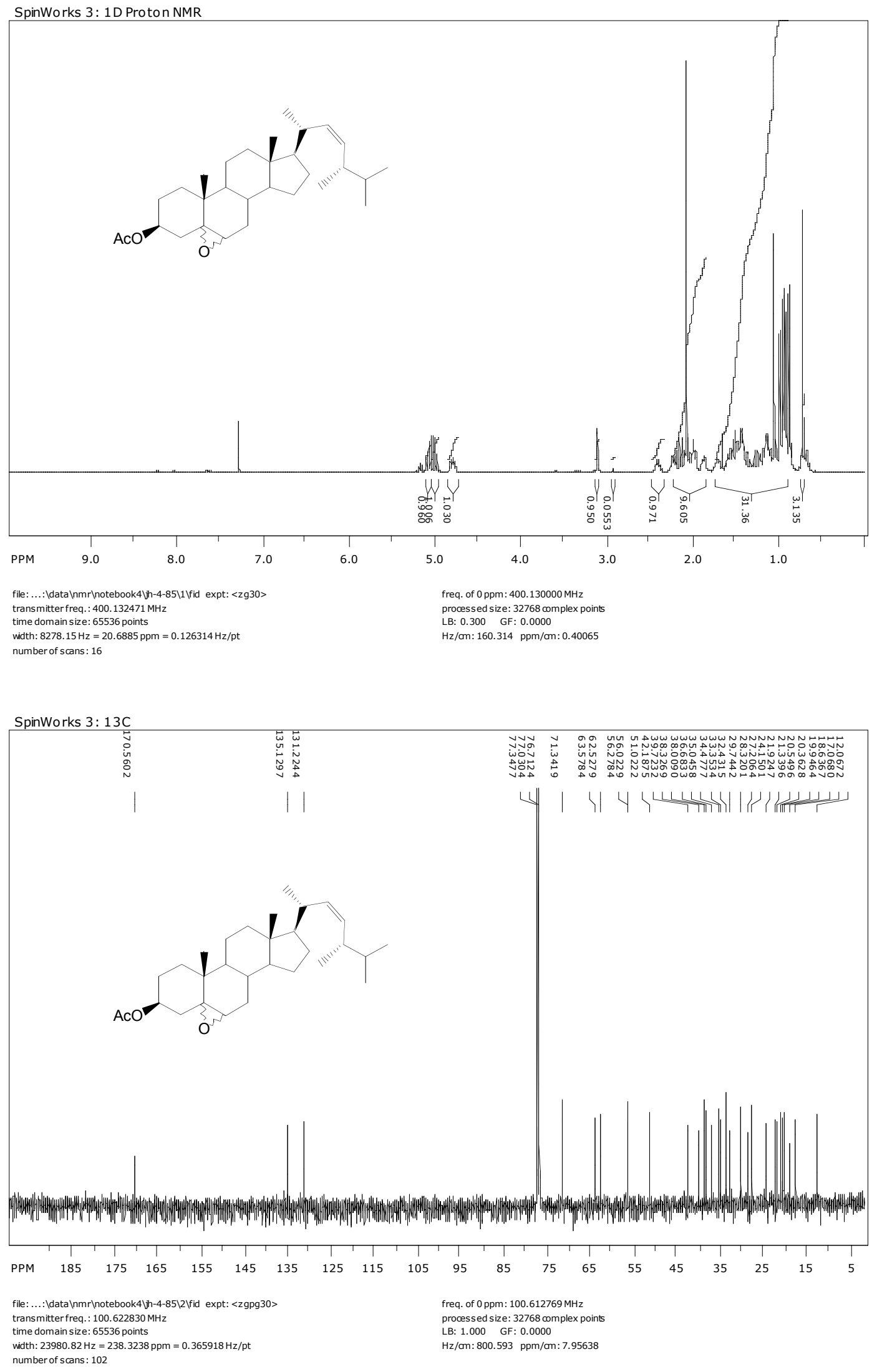

\section{${ }^{1} \mathrm{H}$ and ${ }^{13} \mathrm{C}$ of $12 \mathrm{ab}$}



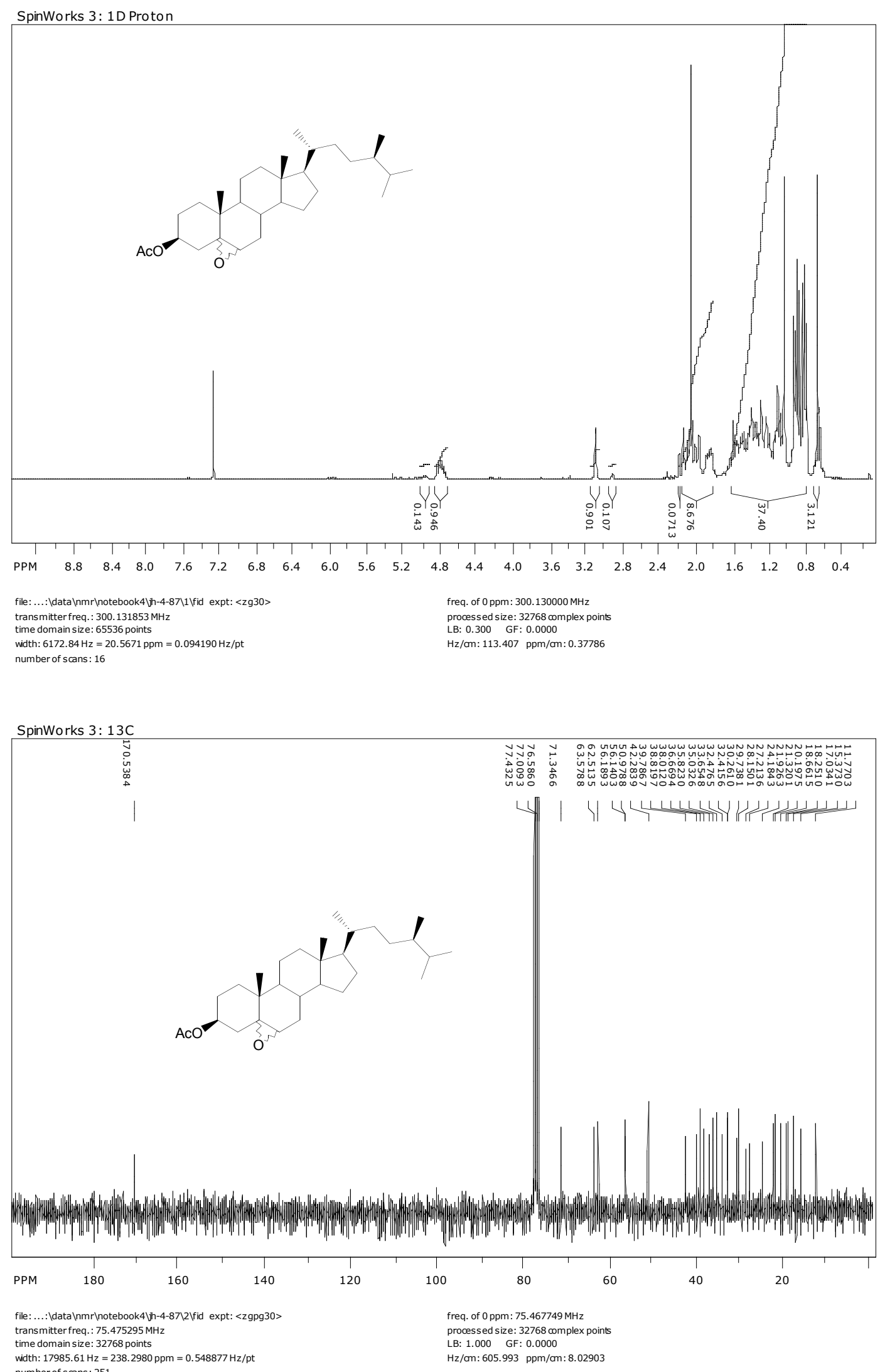

${ }^{1} \mathrm{H}$ and ${ }^{13} \mathrm{C}$ of 13ab 

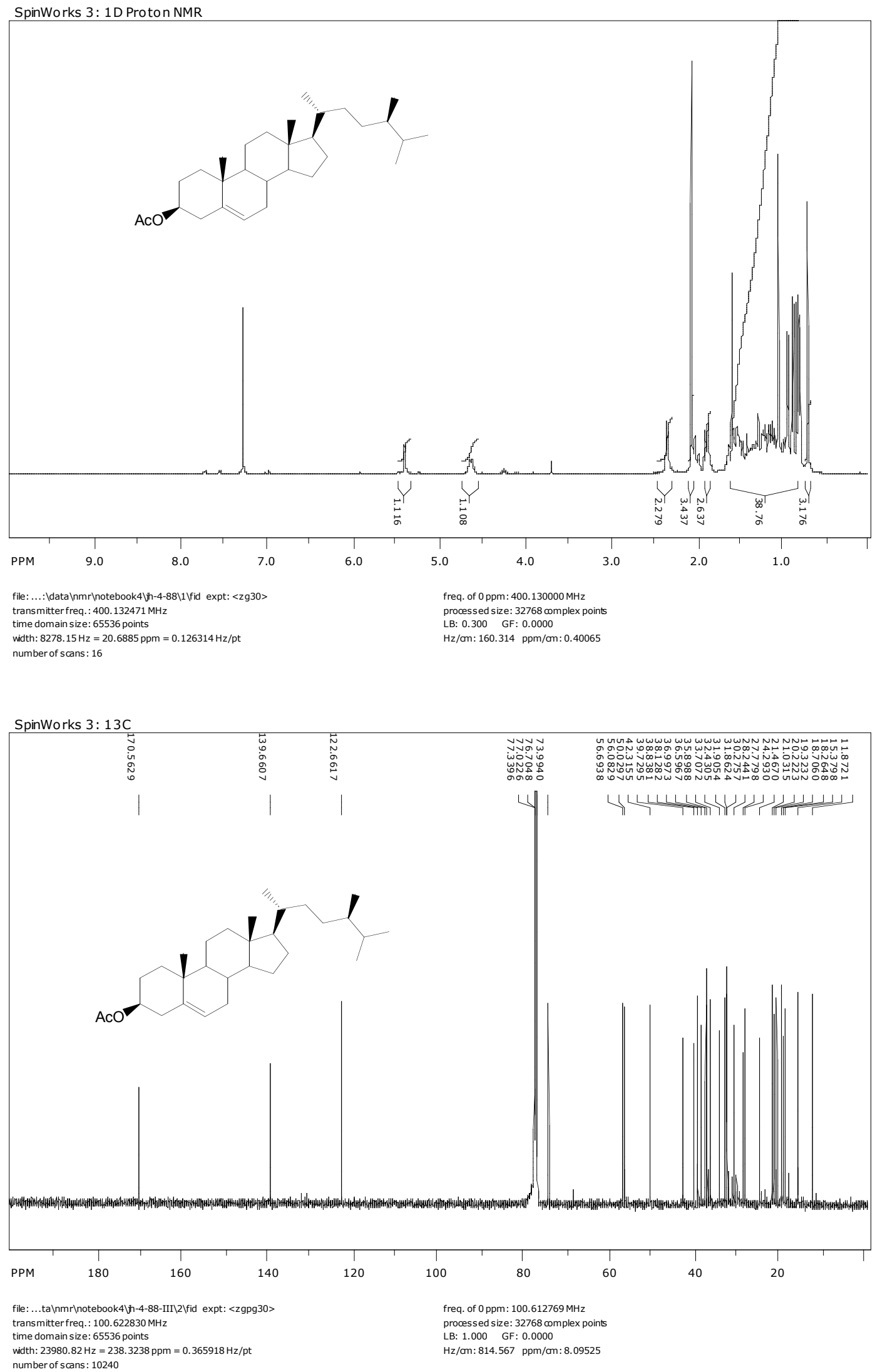

\section{${ }^{1} \mathrm{H}$ and ${ }^{13} \mathrm{C}$ of campesterol acetate (14)}

